The Japanese Journal of Physiology

19, pp. 176-186, 1969

\title{
LIPOLYTIC ACTION OF SEROTONIN IN BROWN ADIPOSE TISSUE IN VITRO
}

\author{
Keiichi Yoshimura, Tsutomu Hiroshige And Shinji IToH \\ Department of Physiology, Hokkaido University School of Medicine, Sapporo
}

Brown adipose tissue is known as one of the major sites of heat production in cold-adapted animals as well as in hibernators undergoing arousal ${ }^{1,2}$. BALL and JUNGAS ${ }^{3)}$ proposed a hypothesis that heat production in brown adipose tissue is due to an acceleration of a process involving triglyceride breakdown and resynthesis. Subsequent works from the same laborator $\mathrm{y}^{4-6)}$ provided ample evidence for the existence of such a process not only in white epididymal but also in brown adipose tissue. It is also claimed ${ }^{4)}$ and later confirmed $^{7)}$ that catecholamines, especially norepinephrine, released from the sympathetic nerve endings within brown adipose tissue, are physiologically important means of activation of the high metabolic capabilities in this tissue. In fact, STOCK and WESTERMANN ${ }^{8)}$ reported the existence of catecholamines in brown adipose tissue in a high concentration.

As to the metabolic activity of serotonin which is also known to exist in brown adipose tissue in a large amount ${ }^{8)}$, VAUGHAN ${ }^{9,10)}$, using epididymal adipose tissue, failed to demonstrate any lipolytic activity in vitro, whereas could show a significant increase in phosphorylase activity in the same tissue. On the other hand, BIECK ${ }^{11)}$ claimed that a significant increase in lipolytic activity was demonstrable following the addition of serotonin in vitro in the presence of pargyline, a potent monoamine oxidase inhibitor. He ascribed the cause for failure reported by previous investigator ${ }^{5,9)}$ to a rapid inactivation of the amine by monoamine oxidase in adipose tissue. These investigators however were concerned exclusively with epididymal adipose tissue and no report has been made on the role of serotonin in fatty acid metabolism of brown adipose tissue in spite of the abundance of serotonin therein ${ }^{8)}$.

In an attempt to clarify this point, comparison was made in the present experiment on the lipolytic effect in vitro of serotonin on epididymal, mesenteric and brown adipose tissues of the rat. Some observations were also made on the effect of serotonin on oxygen consumption by brown adipose tissue in relation to FFA release. The results are discussed with special reference to the mode of action of serotonin in brown adipose tissue.

Received for publication May 9, 1968

吉村啓一, 広重 力, 伊藤真次 


\section{MATERIALS AND METHODS}

Preparation of tissues. Male Wistar rats, weighing 200 to $350 \mathrm{~g}$, were used throughout the experiments. They were housed at a constant ambient temperature of $20 \pm 2^{\circ} \mathrm{C}$. Rat biscuits and water were given ad libitum. All animals were in the fed state at the time of sacrifice. Interscapular brown adipose tissue was dissected out as rapidly as possible and was trimmed virtually free of adhering muscle and white adipose tissue. The tissue was cut rapidly with a razor blade into cubes weighing approximately 3 to $6 \mathrm{mg}$ each. The cubes were then weighed and placed in small flasks containing incubation medium for the purpose of determining free fatty acid (FFA) release, or in Warburg vessels for the determination of oxygen consumption. Approximately equivalent amounts of tissue from the same animal were used for the paired incubation. Epididymal and mesenteric white adipose tissues were rapidly removed, cut into six pieces of a similar size for the use of paired experiments.

Conditions of incubation. For the observation of FFA release, approximately $50 \mathrm{mg}$ of brown adipose tissue or 80 to $120 \mathrm{mg}$ of white adipose tissue were incubated at $37.5^{\circ} \mathrm{C}$ in the Krebs-Henseleit phosphate buffer ( $\mathrm{pH} 7.4)$ for $2 \mathrm{hr}$, with one-half the recommended dose of calcium, albumin was added at a concentration of $2 \mathrm{~g}$ per $100 \mathrm{ml}$, using air as the gas phase with a constant shaking at $100 \mathrm{cpm}$ on a metabolic shaker. For the determination of oxygen consumption, the tissue pieces were incubated at $37.5^{\circ} \mathrm{C}$ in the same medium in Warburg vessels with $100 \%$ oxygen as the gas phase. In some experiments, FFA and glycerol release into the medium were determined at the end of incubation.

Chemical determinations. FFA in the medium was determined by the colorimetric method of DuncomBE ${ }^{12}$ and glycerol by the method of KonN ${ }^{13}$. Monoamine oxidase (MAO) activity in adipose tissue was assayed according to the method of SJOERDSMA et al.14). Reagents used were serotonin creatinine sulfate (Wako Chem. Co.) and theophylline (Wako Chem. Co.). Safrazine, a MAO inhibitor, was kindly supplied by Ono Seiyaku Co.

\section{RESULTS}

Effect of serotonin on the release of FFA from adipose tissues. In TABLE 1 are shown data on FFA release in vitro from various adipose tissues and the effect of serotonin on it. It will be seen that under basal conditions the release of FFA from brown adipose tissue amounts to a three-fold magnitude as compared with other white adipose tissues. As also shown in TABLE 1, addition of serotonin in vitro of a sufficient amount to produce a final concentration of $5 \times 10^{-4} \mathrm{M}$ caused a slight, though significant, increment in FFA release from mesenteric adipose tissue, while in brown and epididymal adipose tissues serotonin had no effect. When the amount of serotonin was reduced to $5 \times 10^{-5} \mathrm{M}$, no effect was observed in all adipose tissues studied.

Lipolytic effect of serotonin in the presence of monoamine oxidase inhibitor. Failure to demonstrate a lipolytic effect of serotonin in brown and epididymal adipose tissues might be due to a rapid inactivation of the amine by mono- 
TABLE 1 .

Effect of serotonin on the release of FFA from adipose tissues.

Values are the mean \pm S.E. of FFA released

in terms of $\mu \mathrm{Eq} / \mathrm{g} / \mathrm{hr}$.

\begin{tabular}{l|c|c|c|c|c|c}
\hline \multicolumn{1}{|c|}{ Adipose tissue } & $\begin{array}{c}\text { Serotonin } \\
\text { concentration }\end{array}$ & $\begin{array}{c}\text { No. of } \\
\text { paired } \\
\text { expt. }\end{array}$ & Control & Serotonin & Difference & $P$ \\
\hline $\begin{array}{c}\text { Brown adipose } \\
\text { tissue }\end{array}$ & $5 \times 10^{-4} \mathrm{M}$ & 12 & $6.93 \pm 0.85$ & $7.83 \pm 1.01$ & $0.90 \pm 0.53$ & $\mathrm{NS}$ \\
$\begin{array}{c}\text { Mesenteric adipose } \\
\text { tissue }\end{array}$ & $5 \times 10^{-4} \mathrm{M}$ & 8 & $1.99 \pm 0.20$ & $2.84 \pm 0.34$ & $0.95 \pm 0.18$ & $<0.01$ \\
$\begin{array}{c}\text { Epididymal adipose } \\
\text { tissue }\end{array}$ & $\begin{array}{l}5 \times 10^{-5} \mathrm{M} \\
5 \times 10^{-4} \mathrm{M}\end{array}$ & 4 & $1.96 \pm 0.11$ & $2.55 \pm 0.18$ & $0.29 \pm 0.23$ & $\mathrm{NS}$ \\
& 6 & $2.38 \pm 0.27$ & $2.91 \pm 0.24$ & $0.53 \pm 0.27$ & $\mathrm{NS}$ \\
\end{tabular}

NS : not significant

amine oxidase (MAO) in these adipose tissues. In order to clarify this point, the effect of MAO inhibitor, safrazine, was tested in the same assay system. Safrazine in a final concentration of $1 \mathrm{mM}$ caused a marked inhibition up to $90 \%$ of MAO activity in brown adipose tissue as shown in TABLE 2 . The

TABLE 2 .

Inhibition of monoamine oxidase (MAO) activity in brown adipose tissue by various concentrations of safrazine. MAO activity was given in terms of the amount of serotonin deaminated ( $\mu \mathrm{g} / \mathrm{g}$ wet tissue/hr). Numbers in parentheses indicate numbers of determinations.

\begin{tabular}{c|l|c|c|c}
\hline $\begin{array}{c}\text { Control } \\
(\mu \mathrm{g} / \mathrm{g} / \mathrm{hr})\end{array}$ & $\begin{array}{l}\text { Concentration of } \\
\text { safrazine (M) }\end{array}$ & $10^{-3}$ & $10^{-4}$ & $10^{-5}$ \\
$\begin{array}{c}166 \pm 8.5 \\
(7)\end{array}$ & $\begin{array}{l}\% \text { inhibition } \\
\pm \text { S.E. }\end{array}$ & $\begin{array}{c}93 \pm 4.0 \\
(3)\end{array}$ & $\begin{array}{c}71 \pm 6.7 \\
(6)\end{array}$ & $\begin{array}{c}58 \pm 3.7 \\
(3)\end{array}$ \\
\hline
\end{tabular}

TABLE 3.

Lipolytic effect of serotonin in the presence of safrazine. Values are the mean \pm S.E. of FFA released in terms of $\mu \mathrm{Eg} / \mathrm{g} / \mathrm{hr}$. These values were obtained from the difference between control and experimental, each consisting of 4 paired determinations. Safrazine was added in the experimental at a final concentration of $1 \mathrm{mM}$.

\begin{tabular}{l|c|c|c}
\hline \multicolumn{1}{c|}{ Tissue } & $\begin{array}{c}\text { Serotonin } \\
\text { concentration } \\
(\mathrm{M})\end{array}$ & $\begin{array}{c}\text { Serotonin } \\
\text { effect }\end{array}$ & $\mathrm{P}$ \\
\hline Brown adipose tissue & $\begin{array}{c}5 \times 10^{-4} \mathrm{M} \\
5 \times 10^{-5} \mathrm{M}\end{array}$ & $-0.03 \pm 0.23$ & $\mathrm{NS}$ \\
Mesenteric adipose tissue & $5 \times 10^{-4} \mathrm{M}$ & $0.24 \pm 0.24$ & $\mathrm{NS}$ \\
Epididymal adipose tissue & $5 \times 10^{-5 M}$ & $0.57 \pm 0.14$ & $<0.05$ \\
& $5 \times 10^{-4} \mathrm{M}$ & $0.29 \pm 0.12$ & $\mathrm{NS}$ \\
& $5 \times 10^{-5 M}$ & $0.19 \pm 0.13$ & $\mathrm{NS}$ \\
\hline
\end{tabular}

NS : not significant 
effect of serotonin was then examined under the effective inhibition of MAO activity. As will be seen in TABLE 3 , the presence of safrazine $(1 \mathrm{mM})$ did not affect the pattern of serotonin action at all, i.e. the amine in an amount of $5 \times 10^{-4} \mathrm{M}$ alone was effective only in mesenteric adipose tissue.

Effect of serotonin on FFA release in the presence of theophylline. Since it is assumed $^{10,11)}$ that some metabolic effects of serotonin are mediated through a specific nucleotide, cyclic $3^{\prime}, 5^{\prime}$-AMP, the effect of theophylline, a potent inhibitor of phosphodiesterase which decomposes the cyclic AMP, was examined. As shown in TABLE 4, theophylline itself, when given in a final concentration

TABLE 4.

Effect of theophylline on the release of FFA from adipose tissues. Values are the mean \pm S.E. of FFA released in terms of $\mu \mathrm{Eq} / \mathrm{g} / \mathrm{hr}$.

\begin{tabular}{l|c|c|c|c|c}
\hline \multicolumn{1}{c|}{ Adipose tissue } & $\begin{array}{c}\text { No. of } \\
\text { paired } \\
\text { expt. }\end{array}$ & Control & $\begin{array}{c}\text { Theo- } \\
\text { phylline } \\
(1 \mathrm{mM})\end{array}$ & Difference & $\mathrm{P}$ \\
\hline Brown adipose tissue & 13 & $5.52 \pm 0.55$ & $6.29 \pm 0.61$ & $0.79 \pm 0.30$ & $<0.02$ \\
Mesenteric adipose tissue & 9 & $1.90 \pm 0.11$ & $4.97 \pm 0.55$ & $3.05 \pm 0.54$ & $<0.001$ \\
Epididymal adipose tissue & 13 & $2.13 \pm 0.26$ & $6.33 \pm 0.43$ & $4.21 \pm 0.47$ & $<0.001$ \\
\hline
\end{tabular}

of $1 \mathrm{mM}$, caused a significant increase in FFA release from all the tissues examined. This effect of theophylline was several times greater in white than in brown adipose tissue. Next, the serotonin effect on FFA release was studied in the presence of theophylline in the incubation medium. As shown in FIGS. 1, 2 and 3, a marked increase of FFA release was observed in all adipose tissues examined. It is seen that in the presence of theophylline in the incubation medium the lipolytic effect of serotonin was dose-dependent with a maximum response at a final concentration of the amine of $5 \times 10^{-5} \mathrm{M}$. The magnitude of the maximal response to serotonin was the greatest in brown adipose tissue and the smallest in epididymal white adipose tissue, mesenteric adipose tissue being the intermediate. In all adipose tissues studied the dosage of serotonin above this maximal level tended to decrease the response as illustrated in FIGS. 1, 2 and 3.

Effect of serotonin on the release of glycerol from mesenteric adipose tissue. The effect of serotonin on glycerol release was examined in mesenteric adipose tissue, since in brown adipose tissue it is difficult to assess the release of glycerol because of the existence of glycerolkinase and in the epididymal tissue a lipolytic response to serotonin appears to be too weak for the present purpose. The results obtained are shown in FIG. 4. Serotonin in the amount of $5 \times 10^{-4} \mathrm{M}$ which caused a significant increase in FFA release was found also to be effective in eliciting a significant increase in glycerol release from 


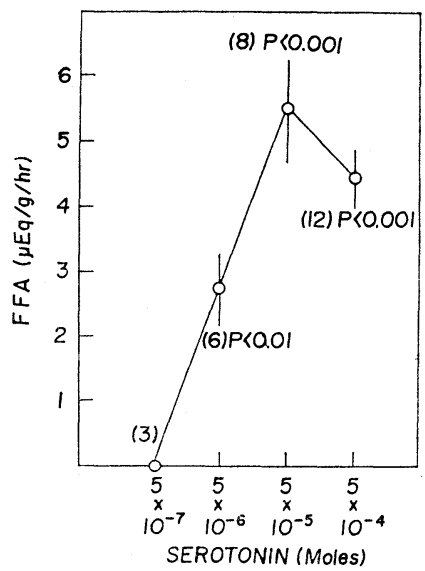

FIG. 1. Effect of serotonin on the release of FFA from brown adipose tissue in the presence of theophylline. Theophylline was added in a final concentration of $1 \mathrm{mM}$. The amount of FFA release induced by serotonin was obtained as difference between control (theophylline alone) and experimental (theophylline plus serotonin) in paired determinations. Numbers in parentheses indicate numbers of determinations. Data are presented as mean and standard error of the serotonin effect.

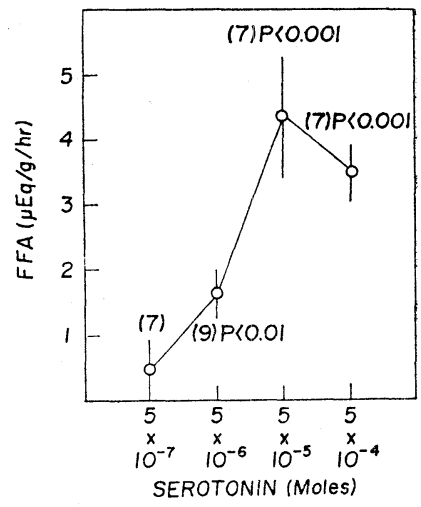

FIG. 2. Effect of serotonin on the release of FFA from mesenteric adipose tissue in the presence of theophylline. See the legend to FIG. 1 for further explanation.

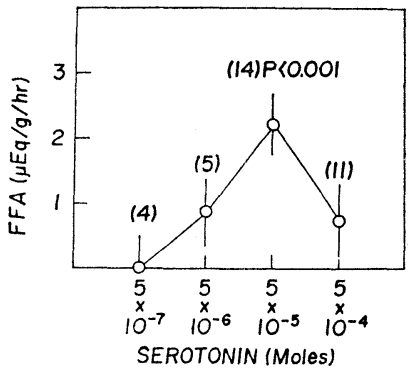

Fig. 3. Effect of serotonin on the release of FFA from epididymal adipose tissue in the presence of theophylline. See the legend to FIG. 1 for further explanation.

mesenteric adipose tissue. Theophylline which was effective in causing FFA release (TABLE 4) was found to induce a significant increase in glycerol release (FIG. 4). When both of the agents were combined in the test system, a marked increase of glycerol release was exhibited by the amount of $5 \times 10^{-4} \mathrm{M}$ of serotenin. Serotonin alone in the amount of $5 \times 10^{-5} \mathrm{M}$ did not show any increase in glycerol release and yet, when combined with $1 \mathrm{mM}$ of theophylline, again induced a marked increase, the magnitude of which being comparable to that seen with $5 \times 10^{-4} \mathrm{M}$ of serotonin (FIG. 4).

FFA release and oxygen consumption by brown adipose tissue under the influence of serotonin in the presence of theophylline. Since the triglyceride breakdown and resynthesis cycle is postulated to accompany an increase in oxygen consumption $^{3-6)}$, oxygen consumption by brown adipose tissue under the influence 


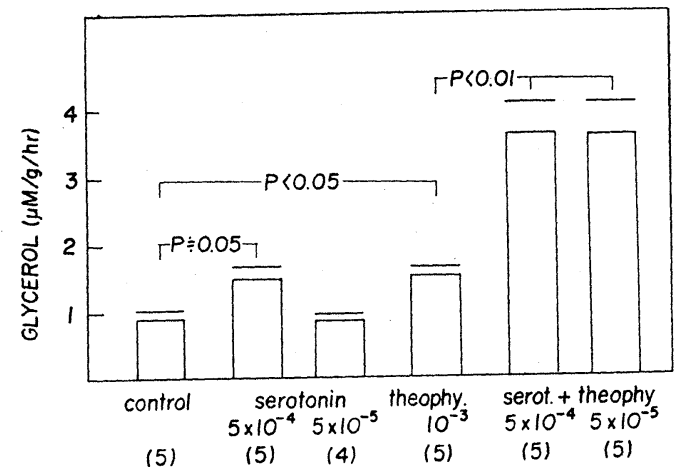

FIG. 4. Effect of serotonin and theophylline on the release of glycerol from mesenteric adipose tissue. Numbers in parentheses denote the number of determinations. Bars at the top of each column represent $\mathrm{S} . \mathrm{E}$. of the mean.

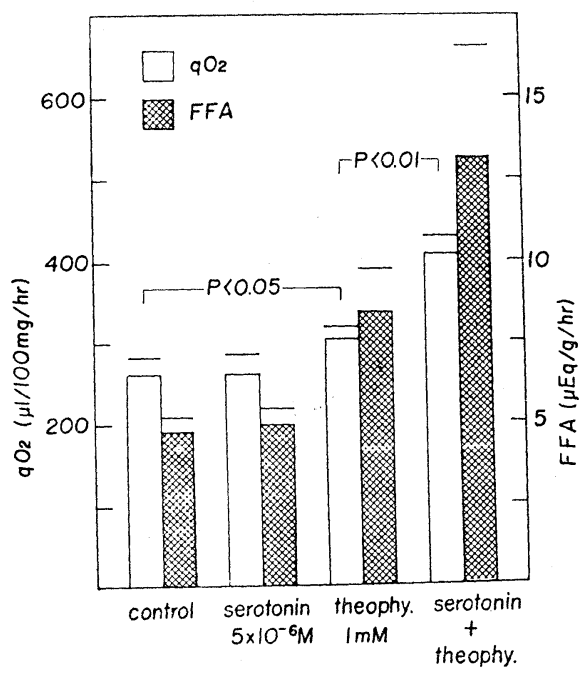

FIG. 5. Increase in oxygen consumption and FFA release by brown adipose tissue due to serotonin plus theophylline. Data are given as mean of seven paired experiments with S.E.

of serotonin was compared with that of FFA release in the presence or absence of theophylline. The results obtained are summarized in FIG. 5. Serotonin alone in the amount of $5 \times 10^{-6} \mathrm{M}$ induced an increment of neither oxygen consumption nor FFA release. It caused however a significant increase of oxygen consumption in the presence of theophylline $(1 \mathrm{mM})$ as shown in FIG. 5. It is also clear that this pattern of change in oxygen consumption, under the influence of serotonin with or without theophylline, goes quite parallel with that of FFA release simultaneously determined. 


\section{DISCUSSION}

The finding by VAUGHAN $^{9,10)}$ that serotonin did not promote lipolysis although it was a potent stimulator of phosphorylase activity in adipose tissue was later confirmed by FRERICHS and BALL ${ }^{5}$. In the present experiment we also have shown that serotonin alone in vitro did not show any lipolytic activity in both the epididymal white and interscapular brown adipose tissue (TABLE 1). It is however of some interest to note that a significant, though small, effect was demonstrated in mesenteric adipose tissue. A similar effect of serotonin on the release of FFA from mesenteric adipose tissue was reported by ITAYA and $\mathrm{UI}^{15}$. They failed also to demonstrate lipolytic action of the amine on epididymal adipose tissue incubated under the same conditions. These authors concluded on the basis of other findings that the observed increase of FFA in the medium was not due to the enhanced lipolysis due to serotonin, but to the inhibition of FFA utilization. Since, however, we have shown (FIG. 4) that a significant increase of glycerol release occurred under the influence of serotonin, we concluded that the increase in FFA release due to serotonin from mesenteric adipose tissue is a consequence of enhanced lipolysis. BIECK ${ }^{11)}$, similarly, claimed a significant increase in lipolytic activity in epididymal adipose tissue by serotonin in vitro in the presence of pargyline, a potent MAO inhibitor, although he did not determine the release of glycerol. BrECK thus concluded that the lack of lipolytic activity of serotonin was mainly due to its rapid inactivation when incubated with adipose tissue. In order to examine this possibility, we have performed a similar experiment, using safrazine as a MAO inhibitor: In spite of the effective inhibition of MAO activity by this agent (TABLE 2), the presence of safrazine in the medium was found not to affect the lipolytic activity of serotonin at all (TABLE 3). The reason for this disparity is not clear for the moment, but it is most unlikely that under the experimental conditions used the degradation of the amine by MAO is rate-limiting.

BIECK in the same report ${ }^{11)}$ claimed that theophylline potentiated the lipolytic action of serotonin. In the present experiments this potentiating action of theophylline was amply confirmed. Furthermore, the potentiation was found most pronounced in brown adipose tissue, followed by mesenteric and epididymal adipose tissues in this order (FIG. 1-3). Since it is well known that theophylline blocks the enzyme phosphodiesterase and prevents the degradation of cyclic $3^{\prime}, 5^{\prime}$-AMP, these results indicate a possible involvement of the nucleotide in the activation of triglyceride lipase in adipose tissue. In fact, BuTscher et al. ${ }^{16,17)}$ advocated strongly the role of the cyclic AMP in the lipolytic response of adipose tissue to epinephrine. Earlier, RIZACK ${ }^{18)}$ reported an activation of an epinephrine-sensitive lipolytic activity from adipose tissue by adenosine $3^{\prime}, 5^{\prime}$-phosphate. WEISS et al. ${ }^{19)}$ was another advocator of the 
cyclic AMP theory, presenting evidence for a role of the nucleotide in adipose tissue lipolysis. Since the potentiation by theophylline was most pronounced in brown adipose tissue, we have performed some preliminary experiments using brown adipose tissue in which the effect of addition of cyclic AMP $\left(10^{-4}\right.$ and $10^{-5} \mathrm{M}$, respectively) was examined with or without theophylline. The results obtained so far showed neither increment of lipolytic activity by cyclic AMP nor potentiation of the activity by theophylline (unpublished observations). The difficulty, on the other hand, to demonstrate a lipolytic activity of cyclic AMP in vitro has been repeatedly emphasized ${ }^{9,10)}$. This was ascribed to poor permeability and also rapid inactivation in the adipose tissue of the nucleotide. In addition, MOSINGER and VAUGHAN ${ }^{20,21)}$ recently reported that lipolytic action of cyclic AMP was markedly influenced by compositional changes in the incubation medium. Consequently, it appears reasonable that failure to demonstrate lipolytic effect of cyclic AMP should not be taken as conclusive, but rather as indicative of complexities involved in the mode of action of cyclic AMP in the activation of triglyceride lipase, as emphasized by Mosinger and VAUGHaN.

The hypothesis proposed originally by BALL and JUNGAS ${ }^{3)}$ that acceleration of triglyceride breakdown and resynthesis cycle is mainly responsible for the increased heat production in brown adipose tissue has been supported by subsequent investigations ${ }^{4-6)}$. Although catecholamine was postulated as a physiologically important means of activation of the above mentioned cycle ${ }^{4}$, no report has been made of serotonin in this regard. The results described in this paper show that serotonin in vitro in a final concentration of $5 \times 10^{-6} \mathrm{M}$, an amount quite ineffective by itself, induced in the presence of theophylline a marked increase in FFA release which was observed most pronouncedly in brown adipose tissue (FIG. 1-3). It is noteworthy that this effect of serotonin was dose-dependent with a maximal response at $5 \times 10^{-5} \mathrm{M}$ of the amine (FIG. 1). It is also of equal importance that this increment of FFA release was accompanied by a similar increase in oxygen consumption in brown adipose tissue (FIG. 5). Since it was reported that serotonin content in brown adipose tissue was $1.07 \mu \mathrm{g} / \mathrm{g}$ of wet tissue weight ${ }^{8}$, a final concentration of the amine in the tissue, assuming a homogeneous distribution, is calculated to be of the order of $10^{-6} \mathrm{M}$ which is well within the range where a linear dose-response relationship was proved.

Using the data obtained with mesenteric adipose tissue, the amount of FFA reesterified was calculated from the amount of glycerol and FFA released (FIGS. 2 and 4), assuming three equivalents of FFA to be released for each glycerol molecule. The value of FFA reesterified in mesenteric adipose tissue under the influence of serotonin in the presence of theophylline was approximately $2.3 \mu \mathrm{M} / \mathrm{g}$. According to BALL and JUNGAS ${ }^{4}$, an esterification of $1.59 \mu \mathrm{M}$ of fatty acid through triglyceride breakdown and resynthesis cycle 
corresponds to each $\mu \mathrm{M}$ of oxygen consumed. Consequently, $2.3 \mu \mathrm{M}$ of FFA reesterified should yield a value of oxygen consumption of $1.45 \mu \mathrm{M}$, i. e. $32.4 \mu \mathrm{l}$ of oxygen. In contrast to this value, a marked increment in oxygen consumption was observed in brown adipose tissue under similar conditions, that is, increase in oxygen consumption due to serotonin in the presence of theophylline was approximately $1,400 \mu \mathrm{l} / \mathrm{g}$ or $63 \mu \mathrm{M}$ with concomitant increment in FFA release of approximately $50 \mu \mathrm{M} / \mathrm{g}$ (FIG. 5). If the ratio of increment in oxygen consumption to that in FFA release is calculated, a value of $63 / 50$ $=1.3$ is obtained for brown adipose tissue and $1.45 / 4.3=0.34$ for mesenteric adipose tissue. The fact that a much more marked increase in oxygen consumption was effected by serotonin with a relatively small increment in FFA release in brown adipose tissue therefore appears to suggest a higher rate of reesterification proceeding actively in brown adipose tissue than in mesenteric white adipose tissue, although this point should be confirmed directly by determining glycerol release from brown adipose tissue. Furthermore, the fact that brown adipose tissue contains glycerolkinase ${ }^{4)}$ and a large amount of glycogen ${ }^{22}$ appears to make this tissue better equipped than white adipose tissue to increase oxygen consumption by triglyceride breakdown and resynthesis. Thus, it is conceivable that increase in oxygen consumption due to serotonin was more pronounced in brown adipose tissue than in white adipose tissue. Accordingly, it would be assumed that serotonin in brown adipose tissue may participate in the thermogenesis through acceleration of a process involving the lipolysis and reesterification cycle in this tissue.

\section{SUMMARY}

In an attempt to know the role of serotonin in fatty acid metabolism of brown adipose tissue, lipolytic action in vitro of this amine was examined in the interscapular brown as well as epididymal and mesenteric white adipose tissues of the rat. It was found that the addition of serotonin in a final concentration of $5 \times 10^{-4} \mathrm{M}$ caused a small, though significant, increment in FFA release from mesenteric adipose tissue, whereas in brown and epididymal adipose tissues serotonin had no effect. This pattern of serotonin effect was not affected at all by the presence of safrazine, a potent monoamine oxidase inhibitor.

However, in the presence of theophylline which blocks phosphodiesterase and prevents the degradation of cyclic AMP, a marked increase of FFA release due to serotonin was observed in all adipose tissues studied, the response being the greatest in brown adipose tissue. It is noteworthy that this action of serotonin was dose-dependent in the dosage range from $5 \times 10^{-7}$ to $5 \times 10^{-5}$ $M$ with a maximum response at the latter concentration. Furthermore, the increment of FFA release by serotonin was found to be accompanied by a 
similar increase in oxygen consumption in brown adipose tissue. It is inferred that serotonin may participate in the thermogenesis through acceleration of a process involving lipolysis and reesterification cycle in brown adipose tissue.

The research reported in this document has been made possible through the support and sponsorship of the U.S. Department of Army, through the USA R and D Group (Far East) Office (Grant No. DA-CRD-AFE-S92-544-67-G87).

\section{REFERENCES}

1) Smith, R.E. ANd Roberts, J.C.: Thermogenesis of brown adipose tissue in coldacclimated rats. Am. J. Physiol., 206: 143 (1964).

2) Smith, R.E. AND Hock, R.J.: Brown fat: thermogenic effector of arousal in hibernators. Science, $140: 199$ (1963).

3) Ball, E.G. And Jungas, R.L.: On the action of hormones which accelerate the rate of oxygen consumption and fatty acid release in rat adipose tissue in vitro. Proc. Nat. Acad. Sci., $47: 932$ (1961).

4) Ball, E.G. ANd Jungas, R.L.: Some effects of hormones on the metabolism of adipose tissue. Recent Prog. Hormone Res., $20: 183$ (1964).

5) Frerichs, H. And BAll, E.G.: Studies on the metabolism of adipose tissue. XI. Activation of phosphorylase by agents which stimulate lipolysis. Biochemistry, 1: 501 (1962).

6) BAll, E.G.: Some energy relationship in adipose tissue. Ann. New York Acad. Sci., $131: 225$ (1965).

7) Joel, C.D.: Stimulation of metabolism of rat brown adipose tissue by addition of lipolytic hormones in vitro. J. Biol. Chem., 241 : 814 (1966).

8) Stock, K. And Westermann, E.O.: Concentration of norepinephrine, serotonin, and histamine, of amine-metabolizing enzymes in mammalian adipose tissue. $J$. Lipid Res., 4 : 297 (1963).

9) VAughan, M.: Effect of hormones on phosphorylase activity in adipose tissue. J. Biol. Chem., $235: 3049$ (1960).

10) Vaughan, M.: The metabolism of adipose tissue in vitro. J. Lipid Res., $2: 293$ (1961).

11) Bieck, P., Stock, K. And Westermann, E.: Lipolytic action of serotonin in vitro. Life Science, 5 : 2157 (1966).

12) Duncombe, W.G.: The colorimetric micro-determination of long chain fatty acids. Biochem. J., $88: 7$ (1963).

13) KORN, E.D.: Clearing factor, heparin-activated lipase. Isolation and characterization of the enzyme from normal rat. J. Biol. Chem., 215:1 (1955).

14) Sjoerdsma, A., Smith, T.E., Stevenson, T.D. And Udenfried, S.: Metabolism of 5-hydroxytryptamine (serotonin) by monoamine oxidase. Proc. Soc. Exp. Biol. Med., $89: 36$ (1955).

15) ITAYA, K. AND UI, M.: The inhibitory action of serotonin on free fatty acid utilization by rat-mesenteric adipose tissue. Biochim. Biophys. Acta, $84: 604$ (1964).

16) Butscher, R.W., Ho, R.J., Meng, H.C. And Sutherland, E.W.: Adenosine 3', $5^{\prime}$-monophosphate in biological materials. II. The measurement of adenosine $3^{\prime}, 5^{\prime}$ monophosphate in tissues and the role of the cyclic nucleotide in the lipolytic response of fat to epinephrine. J. Biol. Chem., $240: 4515$ (1965).

17) Butscher, R.W.: Cyclic $3^{\prime}, 5^{\prime}$-AMP and lipolytic effects of hormones on adipose tissue. Pharmacol. Rev., $18: 237$ (1966). 
18) RIZACK, M.A.: Activation of an epinephrine-sensitive lipolytic activity from adipose tissue by adenosine 3', 5'-phosphate. J. Biol. Chem., 239: 392 (1964).

19) Weiss, B., Davies, J.I. And Brodie, B.B.: Evidence for a role of adenosine 3', 5 '-monophosphate in adipose tissue lipolysis. Biochem. Pharmacol., $15: 1553$ (1966).

20) Mosinger, B. And Vaughan, M.: Effects of electrolytes on epinephrine stimulated lipolysis in adipose tissue in vitro. Biochim. Biophys. Acta, $144: 556$ (1967).

21) Mosinger, B. And Vaughan, M.: The action of cyclic $3^{\prime}, 5^{\prime}$-adenosine monophosphate on lipolysis in rat adipose tissue. Biochim. Biophys. Acta, 144:569 (1967).

22) FawcetT, D.W.: Histological observations on the relation of insulin to the deposition of glycogen in adipose tissue. Endocrinology, 42: 454 (1948). 